ESCRITAS Vol. 9 n. 2 (2017) ISSN 2238-7188 p. 111-130

\title{
O SAMBA NA SALA DE AULA: ENSINANDO HISTÓRIA ATRAVÉS DA MÚSICA POPULAR BRASILEIRA
}

\author{
SAMBA IN THE CLASSROOM: TEACHING HISTORY THROUGH THE \\ BRAZILIAN POPULAR MUSIC
}

\author{
Pedro Luiz do Nascimento Neto*
}

RESUMO: Neste artigo, procuraremos examinar as etapas da formação do samba, revisitando às principais tendências musicais desde suas origens no período Colonial até a contemporaneidade, ressaltando a transformação deste fenômeno para a tradição cultural brasileira. Os resultados apresentados são uma demonstração do quanto o samba teve de resistir para se tornar um importante símbolo da cultura brasileira, podendo ser utilizado no contexto da sala de aula.

PALAVRAS -CHAVE: Samba; sala de aula; sequência didática.

ABSTRACT: In this article we will try to examine the stages of samba formation through the revision of the main musical trends since their origins in the Colonial period until the present time, emphasizing the transformation of this phenomenon into the Brazilian cultural tradition. The results presented are just a demonstration of how much samba had to resist becoming an important symbol of Brazilian culture, and it could be used in the context of the classroom.

KEYWORDS: Samba; classroom; didactic sequence.

\section{INTRODUÇÃO}

Desde muito tempo atrás já se ouviu falar da contribuição africana para a música popular brasileira, porém, neste artigo pretendemos ir além de meras insinuações e demonstrar, baseando-se em documentos históricos diversos na perspectiva da história cultural, as evidências da contribuição dos afro-descendentes para o surgimento de uma vertente musical tipicamente pertencente ao Brasil.

\footnotetext{
* Graduado em História pela UEG, especialista em História e Cultura Afro-brasileira pela FAPAF e mestre em História Social pela UFMA. Atua como professor na rede municipal de ensino em Canaã dos Carajás PA, E-mail: pedroluizneto@hotmail.com.
} 
Nesse sentido, são muito importantes, para se analisar a importância dos aspectos culturais africanos na formação da música popular brasileira as contribuições da corrente historiográfica que diz respeito à discussão quanto à "busca das origens", ou seja, a raiz da "autêntica" música brasileira. Nesta corrente que procura estudar a musica popular a partir de seu contexto social, encontram-se: José Ramos Tinhorão; Waldenyr Caldas e Marcos Napolitano, cujas obras servirão para o norteamento deste estudo acadêmico.

A partir dessa historiografia procuramos desenvolver um pensamento analítico da nossa música, sobretudo do matiz urbano definindo o lugar social do samba numa fala musical coletiva, pura, espontânea, própria da origem africana que, tendo nascido nos morros da cidade do Rio de Janeiro e no Recôncavo Baiano, expressa claramente as raízes dos descendentes de escravos e se afirma na sociedade contemporânea.

Falando de teoria e metodologia, ao utilizarmos a música na sala de aula podemos lançar mão de uma prática pedagógica que promova o diálogo entre o cotidiano escolar e as mais diversas expressões da cultura popular (ABUD, 2010). Nesse sentido, "a música possibilita que abordemos diferentes temáticas como: trabalho, migração, mentalidade, cotidiano, costumes, moda, entre outros" (OLIVEIRA, 2012 p.63), fazendo com que o conteúdo se torne significante para o educando que passa a enxergar com outros olhos a disciplina de história.

Há em nosso entendimento um ganho efetivo ao se trabalhar com a música em sala de aula, pois, de acordo com Circe Maria F. Bittencourt, “O uso da música é importante por situar os jovens diante de um meio de comunicação próximo de sua vivência, mediante o qual o professor pode identificar o gosto, a estética da nova geração. Apesar de todas as vantagens, o uso da música gera algumas questões" (BITTENCOUT, 2009 p.379).

Uma questão que se coloca é quanto ao gênero musical, sabemos que nem todos apreciam os mesmos gostos musicais, e, sobretudo, a juventude tem seus hits preferidos. No entanto, essa é uma oportunidade para introduzir a música popular apresentando-a sempre relacionada à representação que os indivíduos constroem em relação ao momento histórico vivido. Para esse fim, o samba - seja de partido-alto, de roda e/ou de enredo - se presta bastante oportuno (MATTOS, 2011 p.197). Sua trajetória, desde a perseguição sofrida pelos batuques nos terreiros das senzalas coloniais, a sua elevação a ritmo exemplar da brasilidade nos tempos do Estado Novo de Getúlio Vargas, e os grandes desfiles de carnaval do Sambódromo do Marquês de Sapucaí utilizado no período militar como propaganda para o mundo de um país no qual os 
conflitos sociais se resolvem em festa, possibilita a percepção do papel que tem a cultura popular em seu movimento de aproximações e distanciamentos para com os centros de poder ao longo dos períodos históricos. Devemos reconhecer, com isso, que a história do conceito "Samba" traz em seu bojo uma mistura de diferentes estilos musicais abrasileirados cujo resultado final é um gênero exemplar, capaz de esclarecer questões importantes de nosso passado.

Dessa forma, propomos a seguir que o batuque africano foi o principal tronco da manifestação musical popular no Brasil, e dele surgiram diversos ritmos que se espalharam por todo o território nacional, ganharam estilos próprios e instrumentos de sons diferentes. Um desses ritmos - o samba - terminou por se tornar um elemento singular da própria identidade nacional.

\section{LUNDU E UMBIGADA: O SOM PROIBIDO DAS SENZALAS}

Os povos africanos foram afetados pela longa duração da escravidão moderna entre os séculos XV e XIX pela compra e venda de homens, mulheres e crianças negras vendidas como mercadorias num lucrativo comércio transcontinental. Essa transculturação do negro nas Américas através do Atlântico liga a natureza vocal negra ao mito de animador de melodias. Pois cantar era uma forma de expressar os sentimentos como: alegria, tristeza, ansiedade, aborrecimento, raiva, etc. Ela também ditava o ritmo do trabalho seja nas plantações de cana-deaçúcar, nas lavouras de café, na mineração e até na lida dos afazeres domésticos, como nos mostra Gilberto Freire em Casa Grande e Senzala (1930) que as amas de leite negras utilizavam canções de ninar pra embalar o sono dos filhos de seus senhores.

Por conseguinte, no século XVIII aproximadamente, surgiu um dos mais importantes gêneros musicais inventados pelos africanos no Brasil, que foi o Lundu. O lundu foi originalmente uma dança sensual praticada por negros e mulatos em rodas de batuque, só se fixando como canção no final do século XVIII. O lundu é uma música alegre e buliçosa, de versos satíricos, maliciosos, praticado muitas vezes às escondidas nas senzalas dos engenhos coloniais.

FIGURA 1 - Batuque de lundu. 


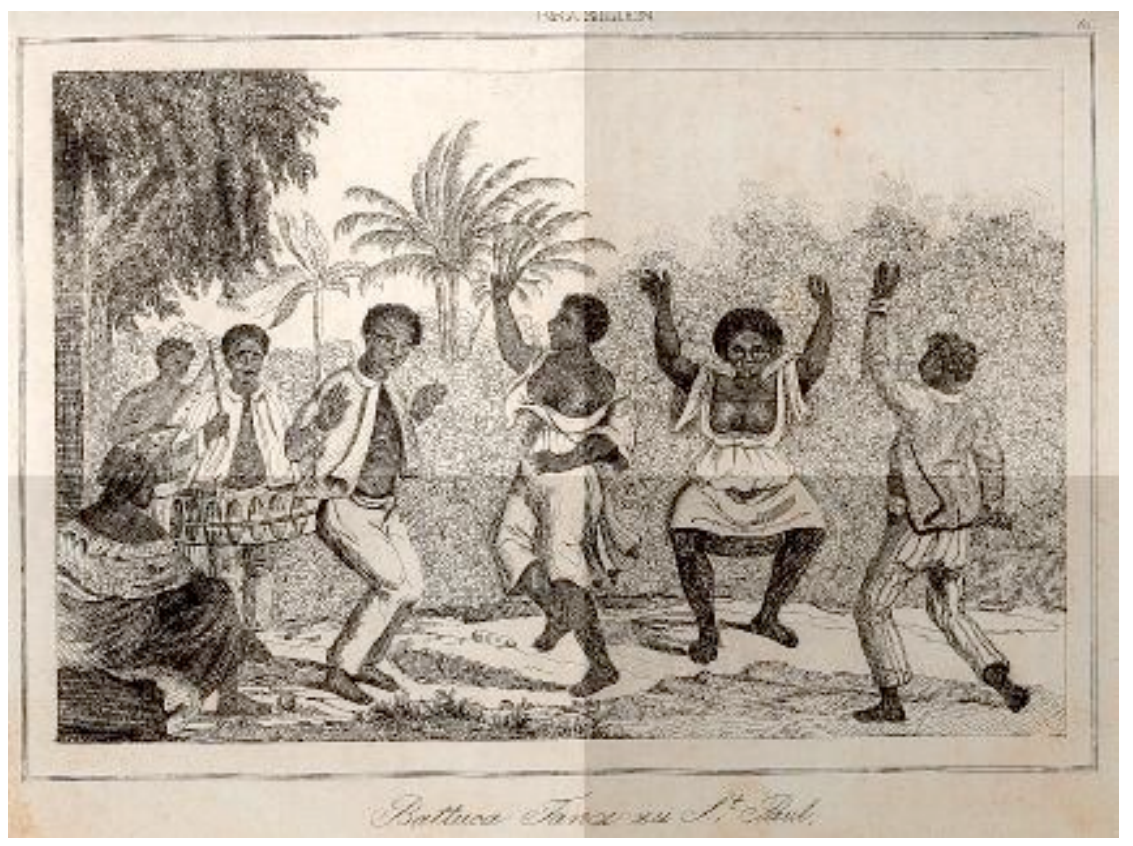

Fonte: http://academia.brasil-europa.eu/ABE-Materiais-Bilder/BatuqueSP-Denis.jpg. Acessado em $1 / 10 / 2015$.

$\mathrm{Na}$ verdade, ele foi fruto da mistura de tradições musicais africanas, portuguesas e indígenas. Sendo que herdou da África o requebrado, a batucada e a sensualidade, de Portugal os instrumentos como o violão e o pandeiro e dos indígenas americanos a pouca vestimenta no trajo de se vestir para os festejos.

Da mesma forma que o lundu, houve também o surgimento da umbigada vinda com os escravos negros da região dos bantos, da qual fazem parte Angola, Congo, Zâmbia e Moçambique, que também ditava seu ritmo no Brasil colonial. Porem sua prática estava mais ligada a rituais de sexualidade e fertilidade. Dançada sempre em dupla, desafiava os dançantes a encostarem os umbigos um no outro, fazendo aquecerem os instintos libidinosos dos negros e das negras. Era vista, no entanto, pelos padres da igreja Católica como a dança do diabo, por isso as autoridades religiosas muitas vezes obrigavam os senhores de engenho a proibirem tais manifestações culturais em seus domínios.

Portanto, é dessa forma que a nossa música surge juntamente com os primeiros centros urbanos, no Brasil colonial do século XVIII, por volta de 1730, quando Salvador e Rio de Janeiro despontavam como as cidades mais progressistas da Colônia. Mas é só a partir do final do século XIX que se configurou a síntese da nossa expressão musical urbana, através dos sambas promovidos por negros e brancos em festas populares, sobretudo religiosas nas quais se destacava 
o hibridismo de sons indígenas, negros e portugueses.

Assim, nossa sociedade que traz em sua formação esse caráter eurocêntrico tem em sua base uma mistura de raças: a indígena, a negra e a européia. E essa mistura disseminou uma polifonia de sons e ritmos permitindo uma diversificação cultural presente em nossa sociedade até os dias de hoje, seja no campo da religião, da culinária, da música e dos costumes.

\section{O LUNDU CANÇÃO OU MODINHA}

A música urbana, o samba e a marcha surgiram e se fixaram por volta de 1870 , constituindo-se em um universo cultural riquíssimo que se estruturou nas raízes africanas. De acordo com Tinhorão (2000), ele chama a atenção para o fato do aparecimento do Lundu ainda no século XVIII, ter marcado o momento de aceitação pela sociedade branca das contribuições declaradamente negras, agora já não representadas somente pela dança de umbigadas, mas também pela música.

Aos poucos o lundu foi deixando de ser proibido e se tornando outro gênero musical de grande repercussão que foi a modinha que teve seu primeiro momento de glória na década de 1770, ela seguiu então pelo resto do século como o nosso melhor meio de expressão poéticomusical da temática amorosa.

Entretanto, essas canções despertam sentimentos de saudade de alguém que partiu de um amor impossível ou de glorificação de um passado. Como estamos vendo, essas características mexem com os sentidos das pessoas de forma alegre e espontânea, as letras e os versos misturam ao som do batuque e esse ritmo descaracteriza as emoções de tristeza através dos movimentos alegre da dança. No fim do século XIX e início do XX, renovada por músicos do povo e sob a forma de canção ternária, assimilada da valsa, a modinha viveu sua fase de maior popularidade, ganhando as ruas como música serenata.

\section{O MAXIXE E A SOBREVIVÊNCIA DO LUNDU}

É interessante notar que o processo de formação da música popular brasileira escoa no leito histórico da constituição das sociedades de classes da urbanização e do desenvolvimento industrial do país, possibilitando a emergência de uma nova classe social, a classe dos músicos 
notáveis. Nesse momento a voz do negro modifica a composição cultural brasileira, isso ocorre através do ressurgimento do lundu, agora com a denominação de maxixe que foi o responsável por sua sobrevivência:

Nesse instante, o maxixe seria de extrema importância para a sobrevivência do lundu. Primeiro, pelo seguinte: herda e mantém a sua estrutura melódica, como já vimos e, portanto, não há o que discutir. O segundo aspecto é ainda mais esclarecedor: o maxixe resgata, recupera a coreografia proibida do lundu. Voltam às ruas (não mais aos salões imperiais) e agora aos bailes de gafieira do Rio de Janeiro, todos os movimentos sensuais, insinuantes e eróticos que caracterizavam a evolução coreográfica do lundu. (CALDAS, 2000, p.14).

Originado de procedimentos empregados pelos músicos de grupos de choro e bandas de coretos do Rio de Janeiro desde o século XIX, o futuro gênero de música popular chamada de maxixe é o primeiro tipo de dança urbana criada no Brasil. A polca européia lhe forneceu o movimento, a habanera cubana lhe deu o ritmo, a música popular afro-brasileira como o lundu e o batuque lhe deram forma. Como se viu, o maxixe nasceu primeiro como dança, só mais tarde a música maxixe, ou o ritmo maxixe, e as composições passaram a trazer impresso em suas partituras o nome de maxixe como gênero. Assim, o maxixe foi o primeiro passo dado para a nacionalização da nossa música popular.

\section{O NASCIMENTO DO SAMBA}

Conforme já observamos, ao longo da nossa história muitas formas de compor melodias, harmonias e ritmos foram inventados sob influência dos africanos trazidos como escravizados de diversas regiões da África, e junto com eles suas manifestações culturais.

Por conseguinte, o samba, uma das principais expressões da música popular brasileira é um exemplo da mistura de práticas musicais negras, indígenas e européias no país. Mais precisamente, esse gênero surgiu da mistura de jongo, batuque de roda de origem banto que ocorria no sudeste, com os toques dos tambores do candomblé, jeje-nagô dos negros da Bahia, Pernambuco e Maranhão. Sendo esses ingredientes agregados a outros de origem indígena e européia.

O toque final foi dado na casa da Tia Ciata, ou melhor, Hilária Batista de Almeida, mãe-de-santo baiana que reuniu em sua residência situada na Rua Visconde de Itaúna em frente 
da Praça Onze, entre o Cais e o porto na cidade do Rio de janeiro, músicos como: José Barbosa da Silva (O sinhô), Ernesto Joaquim Maria dos Santos (O Donga) e João Machado Gomes (O João da baina).

No início da Primeira República, o Brasil deixa de ser apenas um país agrário exportador para dar lugar à industrialização, com isso, as cidades começam a atrair cada vez mais pessoas a procura de emprego e melhores condições de moradia, vestuário e alimentação. Dessa forma, a vida urbana sistematiza a música popular no meio social devido à diversificação e ampliação do público. Pelo desenvolvimento técnico dos meios de produção e comunicação e a emergência de músicos, compositores e cantores em fase de profissionalização.

De acordo com os historiadores Fraga e Albuquerque:

\footnotetext{
Nessa mesma época, um importante personagem foi fundamental para a popularização do samba: Noel Rosa. Noel foi o responsável pela união do samba do morro com o do asfalto. Com a difusão do samba nas rádios de todo o país, no governo de Getúlio Vargas esse tipo de música ganhou o título de "musica oficial" do Brasil. (FRAGA; ALBUQUERQUE, 2009, p.105).
}

O gênero carnavalesco chama a atenção para o ritmo do samba. Em suas composições verificam-se que a música reúne reminiscências de batuques, estribilhos do folclore baiano e sapecado do maxixe carioca por parte dos compositores cariocas de descendência negra que em pouco tempo dominavam os meio de disco e rádio influenciando também outros ritmos como a Bossa Nova e o jazz de origem americana.

\section{A INFLUÊNCIA DO JAZZ}

O Jazz, um estilo musical de origem americana, surgido também nos bairros de população negra, estiliza-se, tornando-se música preferida da classe média, mesmo estando ligado à segregação racial dos negros nortes americanos (HOBSBAWM, 1990 p. 69). E com isso, teve uma grande influência na formação da bossa nova que surge com o fim das grandes orquestras carnavalescas. Essa foi a onda dos pequenos conjuntos a base de piano e bateria, especialistas em tocar música americana nas denominadas boates ou casas noturnas. 
Acredita-se que o Samba conseguiu prevalecer na cultura brasileira por ter nascido da massa operária e por ter sido inserido na classe aristocrática, tendo sofrido algumas alterações com o ritmo da Bossa Nova e com a influência do Jazz. Pois de acordo com José Ramos Tinhorão:

O samba como recorda apareceu no Rio nos primeiros anos do século, exatamente quando no Sul dos Estados Unidos, a Urbanização dos núcleos de população negra ensejada a aparecimento de novos gêneros de música de dança: o Jazz do submundo dos bordéis de storyville [...] inicialmente rurais, iam estilizar-se [...]; canção preferida da classe média Norte Americana. (TINHORÃO, 2000, p.45).

Por conseguinte, com a invasão Norte Americana no mercado brasileiro, ocorrida na segunda metade do século XX, os discos de cantores americanos passam a dominar o país retraindo a nossa música e a solução para esse problema foi o gênero samba-canção que já constituía um produto híbrido de ritmos nacionais. Dessa maneira, muitos sambistas negros foram descobertos pelo grande público nesse momento. Nomes como: Cartola, Nelson Cavaquinho, Ivone Lara, Candeia, Nair Grande, entre outros, passaram a gravar seus discos com grande sucesso nacional.

Percebemos, com isso, que, as culturas negras africanas representaram um instrumento de intercomunicação através dos gingados, batuques, danças e cantos, dada a sua adaptação no ambiente brasileiro. Por isso, permite-se reconhecer, que a produção artística do negro, ao se afirmar, teve primeiro, de resistir à escravidão, aos preconceitos e aos estereótipos quem afloraram e se solidificaram permanentemente. No entanto, sua influência no samba, no pagode, no afoxé, na música folclórica, no funk etc. Constituiu-se uma parte vital de uma visão de mundo, na qual são expressos desejos carnais, sentimentos amorosos, clamores sociais, denúncias de injustiça, esperanças no futuro, etc..

\section{O SAMBA NA SALA DE AULA: UMA PROPOSTA DE SEQUÊNCIA DIDÁTICA}

Propomos que, a partir da trajetória exposta acima, a temática do samba seja abordada na sala de aula. Para isso, recorremos a uma sequência didática de três etapas, nas quais, procurase envolver o educando no cotidiano de um sambista, reconhecendo nas letras de suas canções - 
que falam de tristezas, abandono, desamor, desilusão, velhice, pobreza, drogas, morte, entre outros assuntos - crônicas de vida das populações pobres; negras, pardas e mulatas; analfabetas ou semianalfabetas; e, quase sempre migrantes nordestinos, que habitam os morros cariocas e/ou outros aglomerados urbanos brasileiros.

\section{ETAPA}

Duração: 2 aulas.

Orientações didáticas: Com a participação dos alunos realize uma pesquisa sobre alguns dos principais sambistas brasileiros do século XIX. Sugerimos aqueles que tiveram maior destaque na mídia televisiva, no rádio e na imprensa escrita: Sinhô, Donga, João da baiana, Wilson Batista, Pixinguinha, Noel Rosa, Nelson Cavaquinho, Candeia, Ivone Lara, Nair Grande, Cartola, Adoniran Barbosa, Dorival Caymmi, Bezerra da Silva. Contudo, pode-se incluir outros menos conhecidos do grande público, até mesmo algum que seja reputado na cidade onde o professor e os alunos residem.

\section{Exemplificação:}

TABELA 1 - Biografia de sambistas.

\begin{tabular}{|c|c|c|}
\hline Nelson Cavaquinho & Adoniran Barbosa & Bezerra da Silva \\
\hline Nelson Cavaquinho nasceu & João Rubinato, mais conhecido & José Bezerra da Silva nasceu \\
\hline em 29 de outubro de 1911 & como Adoniran Barbosa, & no ano de 1927 em um bairro \\
\hline no Rio de Janeiro, filho de & nasceu no dia 6 de agosto de & pobre da cidade de Recife em \\
\hline um contra mestres da banda & 1910 em Valinhos, no interior & Pernambuco. O pai era \\
\hline da Polícia Militar e de uma & de São Paulo. Era filho de & marinheiro da Marinha \\
\hline índia nascida no Paraguai. & imigrantes italianos, & mercante e vivia embarcado \\
\hline Estudou pouco e nem & abandonou a escola cedo sem & em viagens visitando a família \\
\hline chegou a concluir o ginásio. & ao menos concluir o primário, & em poucos episódios, até que \\
\hline Foi eletricista, pedreiro, & para ajudar seus pais a criar os & deixou de visitá-los, mudando- \\
\hline soldado da PM e & sete irmãos, entregava & se para o Rio de Janeiro. A \\
\hline funcionário de curtume. & marmitas. Começa sua carreira & mãe, o criou junto com outros \\
\hline Casou-se aos 20 anos com & musical no rádio, que a esta & dois irmãos, José e Vanda, com \\
\hline Alice e tiveram quatro & altura se tornara o meio de & bastantes dificuldades \\
\hline filhos. Em 1952 mudou-se & comunicação mais popular no & trabalhando com lavadeira. Em \\
\hline
\end{tabular}




\begin{tabular}{|c|c|c|}
\hline para o Morro da mangueira & Brasil, se apresentando como & sua infância, fazia bicos para \\
\hline iniciou sua carreira no & um personagem chamado & ganhar alguns trocados. As \\
\hline samba compondo para & Adoniram Barbosa, foi & brigas com o padrasto eram \\
\hline outros artistas como: Cyro & rejeitado em muitas emissoras, & constantes, principalmente, por \\
\hline Monteiro, Clara Nunes e & todavia, não desistiu. Astuto & gostar de frequentar batucadas, \\
\hline Dalva de Oliveira. O & observador da condição & vistas a essa época como coisa \\
\hline reconhecimento só veio em & humana passa a incluir em suas & de vagabundo. Com 15 anos de \\
\hline idade á avançada, quando & composições os dramas vividos & idade, foi por conta própria \\
\hline suas canções chegaram às & pelas pessoas ao seu redor e & para o Rio de Janeiro, na \\
\hline mãos de Nara Leão e & com isso ganha & esperança de rever o pai e se \\
\hline Elizeth Cardoso, artistas da & reconhecimento, inclusive na & estabelecer por lá. Quando \\
\hline classe média carioca. Seus & televisão com Trem das Onze e & finalmente o encontra é \\
\hline versos, cheios de dor e & Saudosa Maloca. & rejeitado e obrigado a se virar \\
\hline sofrimento, arrebatavam os & Morador do Bairro da Mooca - & sozinho na nova cidade. Acha \\
\hline corações desenganados do & um reduto de imigrantes & emprego na construção civil, se \\
\hline amor, tornando suas & italianos vindos pra o Brasil no & especializa com pintor e toca a \\
\hline canções hinos universais na & final do século 19 e início do & vida dormindo nas próprias \\
\hline boca dos amantes, sua & século 20 para trabalhar na & construções onde trabalhava. \\
\hline composição $A$ Flor e o & lavoura e na indústria paulista, & Depois de algum tempo se \\
\hline Espinho lhe deu grande & ilustrou como ninguém o & muda para o Morro do \\
\hline prestígio e o lançou para as & cotidiano dessa comunidade & Cantagalo, no qual reside por \\
\hline novas gerações. A cantora & imortalizando o sotaque ítalo- & 20 anos, e onde estabelece \\
\hline Beth Carvalho foi sua maior & paulistano em sua própria voz. & relacionamentos frustrados \\
\hline pupila e herdeira. Enquanto & Suas canções tinham o caráter & com várias mulheres. Dividia \\
\hline o sucesso aumentava a & de crônicas, ora bem- & seu tempo entre a construção \\
\hline velhice também avançava. & humoradas, ora trágicas, sobre & civil e a música, porém, por \\
\hline Em meio a uma vida & o povo que veio trabalhar na & volta de 1954 , por não arrumar \\
\hline boêmia, debilitada pelo & construção civil da metrópole & mais trabalho, virou morador \\
\hline alcoolismo, pela mágoa & paulistana. Era conhecido pelo & de rua por sete anos. \\
\hline com as opor & vestuário elegante, compos & Conseguiu dar a volta por cima \\
\hline perdidas, pelo amor à & por terno, gravata, chapéu e & depois de ser ajudado pelo já \\
\hline
\end{tabular}




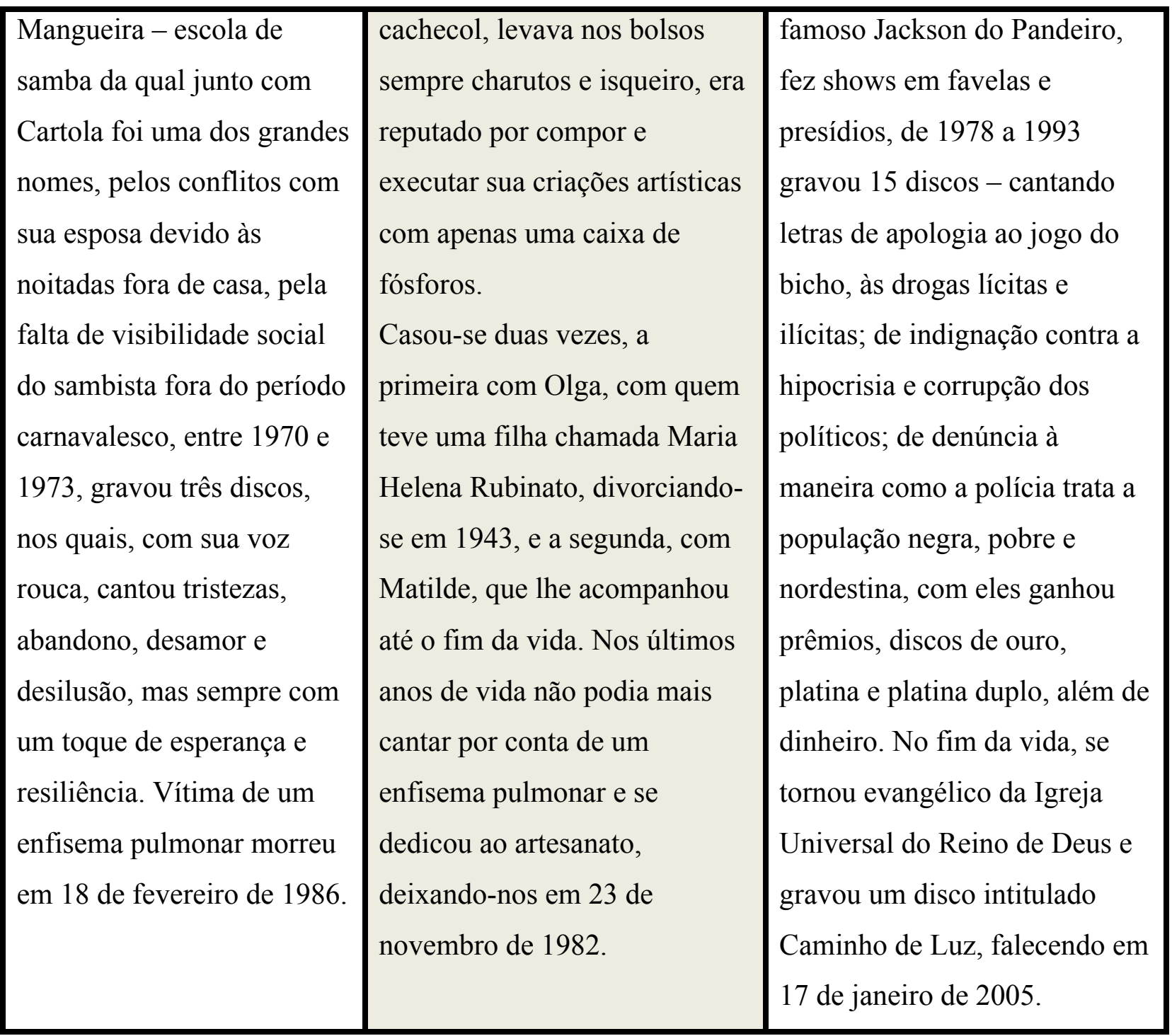

Fonte: SANCHES, 2012 p.16-17/ BRYAN, 2010 p. 36-39/ FILHO; ANDRIETTA; GABIONETA; FRANCO, 2015 p. 36-43.

Apontamentos teórico-metodológicos: Ao nos apropriarmos do trabalho com a biografia de personagens históricos não queremos retornar a noção positivista de que apenas alguns homens sintetizam no percurso de sua própria vida a história de um povo inteiro. Mas, nos apoiamos na concepção de Vany Pacheco Borges, para quem “(...) a biografia é hoje certamente considerada uma fonte para se conhecer a História. A razão mais evidente para se ler uma biografia é saber sobre uma pessoa, mas também sobre uma época, sobre a sociedade em que ela viveu" (BORGES, 2008 p.215). É nesse sentido que as biografias dos sambistas se torna favorável ao desenvolvimento de nossa didática. 
Expectativas de aprendizagem: Espera-se que os alunos aprimorem suas habilidades de sistematização das informações pesquisadas.

\section{ETAPA}

Duração: 2 aulas.

Orientações didáticas: A partir da pesquisa realizada pelos alunos, selecione as informações sobre a vida e obra dos sambistas e construa um quadro comparativo contendo os seguintes topônimos: Nome; Período de vida; Formação escolar; Trajetória de vida; Relacionamentos afetivos; Carreira no Samba; Legado artístico. Considerando o volume de informações recolhidas, é permitido que outros aspectos sejam elencados em relação aos sambistas, desde que encontrem um fim com a temática do samba.

\section{Exemplificação:}

TABELA 2 - Vida e obra dos sambistas.

\begin{tabular}{|l|l|l|l|}
\hline Nome & \multicolumn{1}{|c|}{ Nelson Cavaquinho } & \multicolumn{1}{|c|}{ Adoniran Barbosa } & \multicolumn{1}{c|}{ Bezerra da Silva } \\
\hline veríodo de & Viveu de 1911 a 1986. & $\begin{array}{l}\text { Nasceu em 1910 e faleceu } \\
\text { em 1982. }\end{array}$ & $\begin{array}{l}\text { Nascido no ano de 1927 } \\
\text { e morto no ano de } 2005 .\end{array}$ \\
\hline escolar & $\begin{array}{l}\text { Estudou pouco e nem } \\
\text { chegou a concluir o } \\
\text { ginásio. }\end{array}$ & $\begin{array}{l}\text { Abandonou a escola cedo } \\
\text { sem ao menos concluir o } \\
\text { primário. }\end{array}$ & $\begin{array}{l}\text { Não há registro de que } \\
\text { tenha frequentado a } \\
\text { escola. }\end{array}$ \\
\hline
\end{tabular}




\begin{tabular}{|c|c|c|c|}
\hline $\begin{array}{l}\text { Trajetória } \\
\text { de vida }\end{array}$ & $\begin{array}{l}\text { Nasceu fruto do } \\
\text { relacionamento de um } \\
\text { policial e uma índia } \\
\text { Paraguai, em local } \\
\text { incerto do Rio de } \\
\text { Janeiro, no ano de } 1952 \\
\text { se mudou para o morro } \\
\text { da Mangueira, onde } \\
\text { viveu até o fim de sua } \\
\text { vida. }\end{array}$ & $\begin{array}{l}\text { Seus pais eram imigrantes } \\
\text { italianos que chegados } \\
\text { pelo porto de Santos, } \\
\text { porém, veio a nascer em } \\
\text { Valinhos, se mudando pra } \\
\text { São Paulo na juventude. } \\
\text { Percorreu diversos lugares, } \\
\text { encontrando residência } \\
\text { permanente no bairro da } \\
\text { Mooca. }\end{array}$ & $\begin{array}{l}\text { Teve seu nascimento em } \\
\text { um bairro pobre de } \\
\text { Recife, filho de um } \\
\text { marinheiro e uma } \\
\text { lavadeira. Se torna pintor } \\
\text { na construção civil. Leva } \\
\text { uma vida sofrida no } \\
\text { trabalho, se estabelece no } \\
\text { morro do Cantagalo por } \\
20 \text { anos, fica } \\
\text { desempregado e vai } \\
\text { morar na rua por } 7 \text { anos, } \\
\text { até conhecer Jackson do } \\
\text { Pandeiro. Este, lhe } \\
\text { oferece ajuda, então, } \\
\text { começa uma nova } \\
\text { carreira, a de cantor e } \\
\text { músico. }\end{array}$ \\
\hline $\begin{array}{l}\text { Relaciona } \\
\text { mentos } \\
\text { afetivos }\end{array}$ & $\begin{array}{l}\text { Casou-se aos } 20 \text { anos } \\
\text { com Alice e tiveram } \\
\text { quatro filhos, suas } \\
\text { brigas com a esposa } \\
\text { eram constantes devido } \\
\text { à vida boêmia que } \\
\text { levava. }\end{array}$ & $\begin{array}{l}\text { Casou-se duas vezes, com } \\
\text { Olga, sua primeira esposa, } \\
\text { teve uma filha. Mas foi } \\
\text { Matilde, a derradeira, } \\
\text { quem lhe acompanhou até } \\
\text { o fim da vida. }\end{array}$ & $\begin{array}{l}\text { Teve relacionamentos } \\
\text { frustrados com várias } \\
\text { mulheres. }\end{array}$ \\
\hline $\begin{array}{l}\text { Carreira } \\
\text { artística }\end{array}$ & $\begin{array}{l}\text { Iniciou sua carreira no } \\
\text { samba compondo para } \\
\text { outros artistas, compôs } \\
\text { mais de } 400 \text { canções, se }\end{array}$ & $\begin{array}{l}\text { Frequentou várias } \\
\text { emissoras de rádio em } \\
\text { busca de oportunidades, } \\
\text { em algumas fez }\end{array}$ & $\begin{array}{l}\text { Se envolveu com a } \\
\text { batucada desde menino, } \\
\text { todavia, começa sua } \\
\text { carreira profissional }\end{array}$ \\
\hline
\end{tabular}




\begin{tabular}{|c|c|c|c|}
\hline & $\begin{array}{l}\text { tornou conhecido após } \\
\text { suas composições } \\
\text { serem gravadas por } \\
\text { Nara Leão e Elizeth } \\
\text { Cardoso. Apenas na } \\
\text { velhice pôde gravar } \\
\text { seus próprios discos, se } \\
\text { tornando reconhecido } \\
\text { também como } \\
\text { interprete. Sua } \\
\text { composição A Flor e o } \\
\text { Espinho lhe deu grande } \\
\text { prestígio e o lançou } \\
\text { para as novas gerações. }\end{array}$ & $\begin{array}{l}\text { participações, mas na } \\
\text { maioria foi rejeitado. De } \\
\text { tanto insistir, alcança } \\
\text { relativo sucesso, indo } \\
\text { parar, além do rádio, na } \\
\text { TV Record com as } \\
\text { músicas Trem das Onze e } \\
\text { Saudosa Maloca. }\end{array}$ & $\begin{array}{l}\text { depois de ser ajudado } \\
\text { pelo já famoso Jackson } \\
\text { do Pandeiro, faz shows } \\
\text { em favelas e presídios, } \\
\text { grava discos e ganha } \\
\text { prêmios. Sua música } \\
\text { mais conhecida foi Vou } \\
\text { apertar, mas não vou } \\
\text { acender agora. }\end{array}$ \\
\hline $\begin{array}{l}\text { Legado } \\
\text { para o } \\
\text { samba }\end{array}$ & $\begin{array}{l}\text { Seus versos, cheios de } \\
\text { dor e sofrimento, } \\
\text { arrebatavam os } \\
\text { corações desenganados } \\
\text { do amor, tornando suas } \\
\text { canções hinos } \\
\text { universais na boca dos } \\
\text { amantes. Apadrinhou a } \\
\text { cantora Beth Carvalho. }\end{array}$ & $\begin{array}{l}\text { Suas canções tinham o } \\
\text { caráter de crônicas, ora } \\
\text { bem-humoradas, ora } \\
\text { trágicas, sobre o povo que } \\
\text { veio trabalhar na } \\
\text { construção civil da } \\
\text { metrópole paulistana. }\end{array}$ & $\begin{array}{l}\text { Cantou letras de apologia } \\
\text { ao jogo do bicho, às } \\
\text { drogas lícitas e ilícitas; } \\
\text { de indignação contra a } \\
\text { hipocrisia e corrupção } \\
\text { dos políticos; de } \\
\text { denúncia à maneira como } \\
\text { a polícia trata a } \\
\text { população negra, pobre e } \\
\text { nordestina. }\end{array}$ \\
\hline
\end{tabular}

Fonte: SANCHES, 2012 p.16-17/ BRYAN, 2010 p. 36-39/ FILHO; ANDRIETTA; GABIONETA; FRANCO, 2015 p. 36-43.

Apontamentos teórico-metodológicos: A elaboração de um quadro-resumo dos principais aspectos da vida de um sambista se torna um recurso interessante na medida em que possibilita que os alunos percebam as semelhanças e diferenças entre os personagens pesquisados. Para Luís Augusto Farinatti: "é válido montar tal quadro, em caráter experimental e desconfiar dele. Ou seja, utiliza-lo como um referencial hipotético e realizar cruzamentos com 
outras fontes" (FARINATTI, 2008 p.67). Para tanto, os alunos deverão ser orientados a preencher o quadro com atenção na seleção e organização dos trechos que comporão o quadro, pois o mesmo será exposto para apreciação.

Expectativas de aprendizagem: Pretende-se levar os alunos a compreender a produção de quadro um explicativo, a identificar e registrar fatos e relacioná-los entre si.

\section{ETAPA}

Duração: 2 aulas.

Orientações didáticas: Busque em companhia dos alunos pelo menos uma das músicas de maior destaque de cada sambista. Privilegia aquelas que contenham trechos: engraçados e cheiros de trocadilhos sobre os embates com a lei; que reproduzam o linguajar típico do malandro espontâneo e despreocupado com o futuro, que narrem acontecimentos marcantes para a comunidade em que vivem, relatem desilusão ante as decepções amorosas, despertem a atenção para problemas sociais brasileiros.

\section{Exemplificação:}

TABELA 3 - Analisando letras de sambas.

\begin{tabular}{|c|c|c|c|}
\hline $\begin{array}{l}\text { Nome da } \\
\text { canção }\end{array}$ & A flor e o espinho. & Saudosa Maloca & Eu sou favela. \\
\hline Interprete & Nelson Cavaquinho. & Adoniran Barbosa & Bezerra da Silva \\
\hline $\begin{array}{l}\text { Álbum / ano } \\
\text { de lançamento } \\
\text { / gravadora }\end{array}$ & $\begin{array}{l}\text { Nelson Cavaquinho / } \\
1973 \text { / Odeon }\end{array}$ & $\begin{array}{l}\text { Adoniran Barbosa / } 1974 \\
\text { / Odeon }\end{array}$ & $\begin{array}{l}\text { Presidente Caô Caô / } \\
1992 \text { / BMG-Ariola. }\end{array}$ \\
\hline $\begin{array}{l}\text { Compositor } \\
\text { (es) }\end{array}$ & $\begin{array}{l}\text { Alcides Caminha, } \\
\text { Guilherme de Brito e } \\
\text { Nelson Cavaquinho. }\end{array}$ & Adoniran Barbosa & $\begin{array}{l}\text { Sérgio Mosca e Noca } \\
\text { da Portela. }\end{array}$ \\
\hline $\begin{array}{l}\text { Trecho da } \\
\text { Letra }\end{array}$ & $\begin{array}{l}\text { Tire o seu sorriso do } \\
\text { caminho } \\
\text { Que eu quero passar com } \\
\text { a minha dor } \\
\text { Hoje pra você eu sou }\end{array}$ & $\begin{array}{l}\text { Foi aqui seu moço } \\
\text { Que eu, Mato Grosso e o } \\
\text { Joca } \\
\text { Construímos nossa } \\
\text { maloca }\end{array}$ & $\begin{array}{l}\text { Sim, mas, } \\
\text { A favela, nunca foi } \\
\text { reduto de marginal } \\
\text { "Eu falei" } \\
\text { A favela, nunca foi }\end{array}$ \\
\hline
\end{tabular}




\begin{tabular}{|c|c|c|c|}
\hline & $\begin{array}{l}\text { espinho } \\
\text { Espinho não machuca a } \\
\text { flor } \\
\text { Eu só errei quando juntei } \\
\text { minh'alma a sua } \\
\text { O sol não pode viver } \\
\text { perto da lua }\end{array}$ & $\begin{array}{l}\text { Mais, um dia } \\
\text { Nós nem pode se } \\
\text { alembrar } \\
\text { Veio os homi cas } \\
\text { ferramenta } \\
\text { Que o dono mandô } \\
\text { derrubá } \\
\text { Peguemo todas nossas } \\
\text { coisa } \\
\text { E fumos pro meio da rua } \\
\text { Apreciar a demolição } \\
\text { E prá esquecê nóis } \\
\text { cantemos assim: } \\
\text { Saudosa maloca, maloca } \\
\text { querida, } \\
\text { Que dim donde nóis } \\
\text { passemos dias feliz de } \\
\text { nossa vida }\end{array}$ & $\begin{array}{l}\text { reduto de marginal } \\
\text { Só tem gente humilde } \\
\text { Marginalizada } \\
\text { e essa verdade não sai } \\
\text { no jornal } \\
\text { A favela é, um } \\
\text { problema social } \\
\text { A favela é, um } \\
\text { problema social }\end{array}$ \\
\hline $\begin{array}{l}\text { Tema } \\
\text { abordado }\end{array}$ & Desilusão amorosa. & $\begin{array}{l}\text { Despejo de terreno pela } \\
\text { polícia. }\end{array}$ & $\begin{array}{l}\text { A favela como } \\
\text { problema social. }\end{array}$ \\
\hline $\begin{array}{l}\text { Análise dos } \\
\text { Elementos de } \\
\text { identidade }\end{array}$ & $\begin{array}{l}\text { Nessa tristonha canção } \\
\text { há um tom intimista que } \\
\text { leva à reflexão. } \\
\text { Diferentemente de outros } \\
\text { sambas que são } \\
\text { executados de forma } \\
\text { eufórica, existe nesta } \\
\text { composição de Nelson } \\
\text { Cavaquinho, muito de }\end{array}$ & $\begin{array}{l}\text { Na linguagem } \\
\text { espontânea de Adoniran } \\
\text { Barbosa, um típico } \\
\text { imigrante italiano } \\
\text { morador de algum dos } \\
\text { bairros tradicionais } \\
\text { paulistanos como Bexiga, } \\
\text { Brás, Barra Funda, } \\
\text { Capão Redondo, ou a }\end{array}$ & $\begin{array}{l}\text { Favela é o assunto } \\
\text { predileto de Bezerra } \\
\text { da Silva. Sua trilogia } \\
\text { Aqueles morros } \\
\text { (1982), Saudação às } \\
\text { favelas (1985) e As } \\
\text { favelas que não } \\
\text { exaltei, enaltece um } \\
\text { modo de vida próprio }\end{array}$ \\
\hline
\end{tabular}




\begin{tabular}{|c|c|c|c|}
\hline & $\begin{array}{l}\text { sua melancolia. A } \\
\text { riqueza das harmonias } \\
\text { transparece uma alma } \\
\text { introspectiva, acalentada } \\
\text { pela possibilidade de } \\
\text { exprimir os sentimentos } \\
\text { em forma de canto. } \\
\text { Percebemos, com isso, } \\
\text { ser o interprete herdeiro } \\
\text { do banzo africano, } \\
\text { espécie de nostalgia que } \\
\text { acometia os escravizada } \\
\text { nas Américas, levando } \\
\text { inclusive à morte } \\
\text { (LOPES, 2006 p.27). } \\
\text { Assemelhando-se aos } \\
\text { cantores de blues norte- } \\
\text { americanos, dentre eles: } \\
\text { Muddy Waters, Robert } \\
\text { Johnson e John Lee } \\
\text { Hooker, cujas canções } \\
\text { em forma de lamento } \\
\text { relatavam o duro trabalho } \\
\text { nas lavouras de algodão, } \\
\text { a violência dos } \\
\text { capatazes, as injustiças e } \\
\text { a falta de fé no futuro. }\end{array}$ & $\begin{array}{l}\text { própria Mooca, da } \\
\text { primeira metade do } \\
\text { século 20, narra a } \\
\text { destruição do barraco que } \\
\text { havia construído com } \\
\text { tanto esforço junto a seus } \\
\text { companheiros Mato } \\
\text { Grosso e Joca. Mas que } \\
\text { houvera sido posto a } \\
\text { baixo pelas autoridades, } \\
\text { se tornando o lugar num } \\
\text { algo edifício. Assim, o } \\
\text { compositor encontra uma } \\
\text { forma de manter } \\
\text { preservada na memória } \\
\text { das futuras gerações, } \\
\text { momentos históricos } \\
\text { vividos por boa parte dos } \\
\text { paulistanos que } \\
\text { acompanharam as } \\
\text { transformações pela qual } \\
\text { passou a maior metrópole } \\
\text { do Brasil. }\end{array}$ & $\begin{array}{l}\text { de comunidades de } \\
\text { todo o Rio de Janeiro. } \\
\text { Aqui, mesmo não } \\
\text { sendo o autor, escolhe } \\
\text { gravar uma música } \\
\text { que procura em seu } \\
\text { discurso se posicionar } \\
\text { contra o preconceito } \\
\text { aos moradores das } \\
\text { favelas. Dessa forma, } \\
\text { são denunciados: a } \\
\text { visibilidade negativa } \\
\text { transmitida pelos } \\
\text { veículos de mídia } \\
\text { televisiva; a repressão } \\
\text { policial } \\
\text { indiscriminada aos } \\
\text { habitantes das favelas } \\
\text { como se todos fossem } \\
\text { criminosos; a } \\
\text { injustiça social pela } \\
\text { falta de investimentos } \\
\text { públicos em } \\
\text { saneamento básico, } \\
\text { saúde e educação. }\end{array}$ \\
\hline
\end{tabular}

Fonte: SANCHES, 2012 p.16-17/ BRYAN, 2010 p. 36-39/ FILHO; ANDRIETTA; GABIONETA; FRANCO, 2015 p. 36-43.

Apontamentos teórico-metodológicos: Quando nos utilizamos da interpretação de uma letra de música em sala de aula devemos ter o entendimento de que não se pode forçar uma 
relação entre o discurso da canção e o contexto histórico ao qual se está trabalhando (MORAES, 2000 p.212), apesar de muitas canções expressarem conexão direta com certos períodos históricos, outras estão voltadas para fatos corriqueiros e cotidianos, como parece ser o caso de A flor e o Espinho de Nelson Cavaquinho. No entanto, o professor pode explorar a manifestação da identidade africana do autor por meio da melancolia de suas canções que se assemelham a outros gêneros marcantemente oriundos da negritude nas Américas como: o Jazz, o Blues e a Cumbia. Igualmente, a letra de música pode ser vista como um monumento de apreensão da memória coletiva de um povo (HALBWACHS, 2004 p.30), e assim, compreendemos o importante papel de Andoniran Barbosa, que à semelhança dos antigos griôs africanos, manteve viva uma tradição oral na qual são transmitidos sentimentos de pertencimento a uma comunidade lembrança de acontecimentos históricos vividos coletivamente. Um exemplo de estreita ligação entre a letra de uma música e a vida de um grupo social é a música Eu sou favela de Bezerra da Silva. Os problemas sociais de uma favela salta aos olhos com exemplos do cotidiano, levando ao ouvinte um testemunho da realidade vivida por milhões de brasileiros até hoje. Desta feita, acaba por se constituir mecanismo de representação da realidade (NAPOLITANTO, 2008 p.236).

Expectativas de aprendizagem: Busca-se que os alunos obtenham autonomia para analisar discursos presentes em documentos históricos percebendo hábitos do cotidiano, lutas sociais, ausências de políticas públicas.

\section{CONSIDERAÇÕES FINAIS}

Embora o Samba tenha origem no Rio de Janeiro, para alguns, e/ou no recôncavo baiano, para outros, por volta do início do século XX, sua tradição cultural remete aos primeiros momentos da colonização portuguesa no Brasil.

O samba ao resistir aos percalços encontrados nos vários setores da música brasileira, retorna no cenário musical tentando preservar de maneira sistematizada a tradição cultural africana, e nos dando a idéia de um passado que expressa a mais gloriosa fase da música, pois, foi um período em que compositores se profissionalizaram. Nesse ínterim, influenciando pelo mercado do Jazz, ele surge como produto comercial e aparecem novos sambistas, em que alguns destes expressam os anseios sociais do momento como; amor, sofrimento, denúncia e crítica social. 
Sendo que, ao contrário do que muitos pensam, o samba não está presente só no carnaval, ele faz parte de nossa vida cotidiana sendo cantado e dançado por indivíduos de todos os contextos sociais, pois transmite a alma de um povo cujo coração bate em ritmo acelerado.

Portanto, como demonstrado em forma de sequência didática, o samba encontra lugar na sala de aula, ao se tratar questões contemporâneas, mas que são na verdade reverberações de um passado não tão distante, em que a população negra nos mais diferentes locais do Brasil foram alijadas do direito à cidadania, encontrando regalo na voz e batuque do samba.

\section{REFERÊNCIAS}

FRAGA, Walter; ALBUQUERQUE, Vlamyra R. de. Uma história da cultura afro-brasileira. - São Paulo: Moderna, 2009.

ARAUJO, Kelly Cristina. Áfricas no Brasil. São Paulo: Scipione, 2003.

BEYER, Esther; KEBACH, Patrícia (Orgs). Pedagogia da música: experiências de apreciação musical na sala de aula. Porto Alegre: Mediação, 2009.

BITTENCOURT, Circe Maria Fernandes. Ensino de história: fundamentos e métodos. $-3^{\circ}$ ed. São Paulo: Cortez, 2009.

BORGES, Vany Pacheco. Fontes biográficas: Grandezas e misérias da biografia. In: Fontes históricas / Carla Bassanezi Pinsky (organizadora), 2 ed., $1^{\text {a }}$ reimpressão. - São Paulo: Contexto, 2008 .

BRYAN, Guilherme. A linguagem ítalo-brasileira: O centenário de Adoniran Barbosa. Língua Portuguesa. $\mathrm{n}^{\circ}$ 58, pp.36-39, ago. 2010.

BURKE, Peter. A Escola dos Annales (1929-1989): a Revolução Francesa da historiografia. São Paulo: Fundação Editora da UNESP, 1997.

CALDAS, Waldenyr. Iniciação à música popular brasileira. Brasília: Ática, 2000. (Coleção Primeiros Passos).

CASCUDO, Luís da Câmara. Made in África: pesquisa e notas. 4ª ed., São Paulo: Global, 2002.

DAVIS, Darien J. Afro- brasileiros hoje. São Paulo: Selo Negro, 2000.

FARINATTI, Luís Augusto. Construção de séries e microanálise: notas sobre o tratamento de fontes para a História Social. Anos 90. Porto Alegre, n.15, jul. 2008.

FILHO, Fernando Pedrazolli; ANDRIETTA, Lucas Salvador; GABIONETA, Robson; 
FRANCO, Thiago. Bezerra da Silva: voz e produto do morro. Filosofia Ciência e Vida. ${ }^{\circ}$ 110, pp.36-43, set. 2015.

FREYRE, Gilberto. Casa Grande e Senzala: formação da família brasileira sob o regime da economia patriarcal. $38^{\mathrm{a}}$ ed. Rio de Janeiro: Record, 2000.

FRAGA, Walter; Wlamyra R. de Albuquerque. Uma história da cultura afro-brasileira. São Paulo: Moderna, 2009.

GOFF, Jacques Le. (Org). A história nova. 4ª ed., São Paulo: Martins Fontes, 1988.

HALBWACHS, M. A memória coletiva. - São Paulo: Editora Centauro, 2004.

HERNANDEZ. Leila Maria Gonçalves Leite. A África na sala de aula: visita à história contemporânea. - 2. ed. rev. - São Paulo: Selo Negro, 2008.

HOBSBAWM, Eric J. História social do Jazz. - Rio de Janeiro: Paz e Terra, 1990.

LOPES, Nei. Dicionário escolar afro-brasileiro. - São Paulo: Selo Negro Edições, 2006.

MATTOS, Regina Augusto de. História e cultura afro-brasileira. - 2. - São Paulo: Contexto, 2011.

MORAES, J. G. V. História e música: canção popular e conhecimento histórico. In: Revista Brasileira de História. - São Paulo, v.20, n.39, 2000.

NAPOLITANO, Marcos. A síncope das idéias: a questão da tradição na música popular brasileira. $1^{\text {a }}$ Ed. São Paulo: Editora Fundação Perseu Abramo, 2007.

Fontes audiovisuais: A história depois do papel. In: Fontes históricas / Carla Bassanezi Pinsky (organizadora), 2 ed., $1^{\text {a }}$ reimpressão. - São Paulo: Contexto, 2008.

OLIVEIRA, Regina Soares de (org.). História. - São Paulo: Blucher, 2012. (Coleção a reflexão e a prática no ensino; 6).

SANCHES, Pedro Alexandre. O pranto do poeta: Há cem anos nascia Nelson Cavaquinho. Carta na Escola. $n^{\circ}$ 62, pp.16-17, jan. 2012.

TINHORÃO, José Ramos. Música popular: um tema em debate. $3^{\mathrm{a}}$ ed. São Paulo: Edit. 34, 2000. 